\title{
The relationship between self-regulated learning and metacognitive strategies of reading and problems of learning in second language Among bilingual students (Fitting a structural model)
}

\author{
$\underline{\text { Omid Isanejad }}^{1}$, Hasan Alidadi ${ }^{2}$ \\ 1- Ph. D, Department of Counseling, University of Kurdistan, Sanandaj, Iran. ORCID: 0000-0002-8993-1391 \\ E-mail: o.isanejad@uok.ac.ir \\ 2- M.A, Department of Counseling, University of Kurdistan, Sanandaj, Iran. ORCID: 0000-0002-5541-9381
}

Received: 30/07/2018

Accepted: 22/11/2018

\begin{abstract}
Introduction: Bilingual students have some problems about learning due to differences between educational and mother language, that self-regulatory and metacognitive strategies can moderate it.
\end{abstract}

Aim: The present study was conducted to examine the relationship between self-regulated learning and metacognitive strategies of reading and problems of learning in second language among bilingual students.

Method: The research method was descriptive-correlational. A total number of 390 participants were selected randomly. Motivated Strategies for Learning Questionnaire (MSLQ), Metacognitive Awareness of Reading Strategies Inventory (MARSI), and Colorado Learning Difficulties Questionnaire (CLDQ) were utilized to collect the required data.

Results: Fitting the structural model showed that there was a negative relationship between self-regulated learning and metacognitive strategies of reading and problems of learning in second language.

Conclusion: According to these results, exploration and enhancing of self-regulated learning and metacognitive strategies could help bilingual students to solve learning problems and improve academic performance.

Keywords: Self-regulated learning, Metacognitive strategies of learning, Problems of learning, Bilingual 


\section{رابطهى خودتنظيمى يادكيرى و راهبر دهاى فراشناختى خواندن با مشكلات يادكيرى

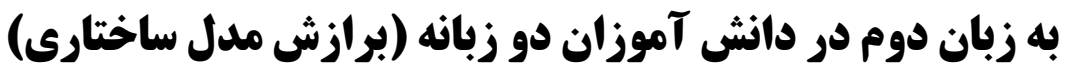

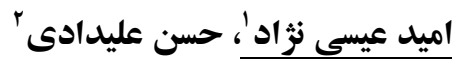

ا.استاديار، گروه مشاوره، دانشكاه كردستان، كردستان، ايران. ايميل: O.isanejad@uok.ac.ir r. كارشناسى ارشد، گروه مشاوره، دانشگاه كردستان، كردستان، ايران.

مقدمه: افراد دوزبانه به دليل متفاوت بودن زبان مادرى شان با زبان رسمى در زمينه يادگيرى با مشكلاتى مواجه هستند كه شيوه خودتنظيمى و راهبردهاى فراشناختى مى تو انند آن را تعديل نمايند. هدف: يُزوهش حاضر با هدف بررسى رابطه بين خودتنظيمى يادگيرى و راهبردهاى فراشناختى خواندن با مشكلات ياد گيرى به زبان دوم در دانش آموزان دو زبانه انجام شد.

روش: مطالعه حاضر توصيفى از نوع همبستخى بود. .جه دانش آموز به شيوه تصادفى از ميان دانش آموزان دختر و يسر دوزبانه

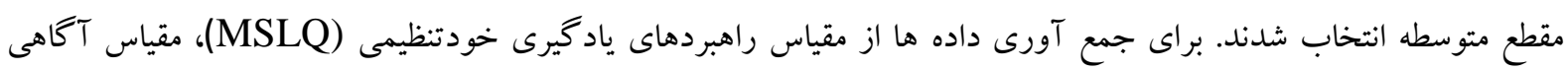

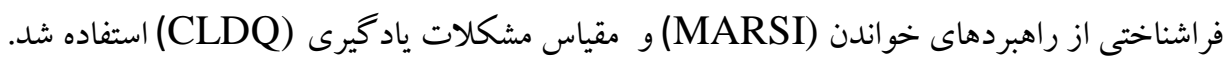

يافته ها: برازش مدل ساختارى نشان داد كه بين خودتنظيمى ياد گيرى و راهبردهاى فراشناختى خواندن با مشكلات يادگيرى به

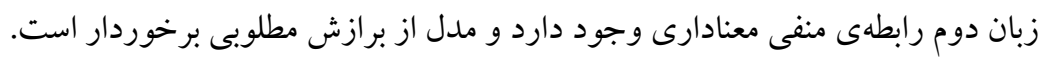
نتيجه كيرى: به نظر مى رسد شناسايى و ارتقاى راهبردهاى خودتنظيمى و فراشناختى در برنامهاى آموزشى احتمال بروز

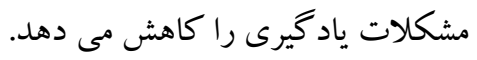
كليد وازهها: خودتنظيمى ياد گيرى، راهبردهاى فر اشناختى خو اندن، مشكلات ياد گيرى، دو زبانه بودن 
هر كدام از آنها سبب ايجاد مشكلات ياد گيرى مى -

افراد دو زبانه به دليل متفاوت بودن زبان مادرى شان با زبان رسمى كه در مدارس آموزش از طريق آن صورت مى يذيرد در ابعادِ مختلف, تحصيلى نظير خواندن، نوشتن، صحبت كردن و حتى حساب كردن با مشكلات بيشترى نسبت به افراد تكك زبانه مواجه

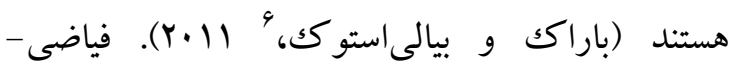
بارجينى (1/N9) در بيزوهش خويش نشان مىدهد كه طول جمله و ميانگين تعداد كلمات در كودكان دو زبانه كمتر از كودكان تكك زبانه است و همينين ساخت نحوى دو زبانه در زبان فارسى سادهتر و توانايىهاى بايينترى در حيطه معنا شناختى در كود كان دو زبانه ديده مىشود. شفيعى و مهر - عليان

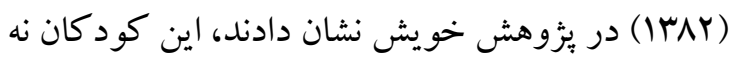
تنها دجار مشكلات كفتارى هستند بلكه در خواندن و و نوشتن نيز با مشكلاتِ زيادى مواجه هستند، هميجنين

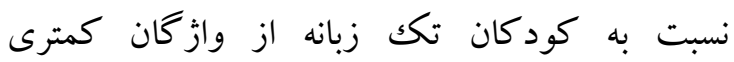
برخوردار هستند و تلفظٍ آنها دجهار اختلال است.

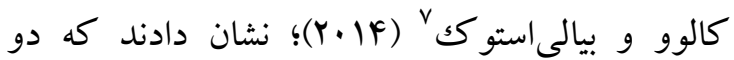
زبانهها نسبت به كودكان تكك زبانه در رشد شناختى دجار مشكل مىشوند امرى كه در عملكردهاى تحصيلى خواندن، درك مطلب و حتى رياضيات مشكل ايجاد مى كند. إنگَالدى آبريو، كروزسانتوس،

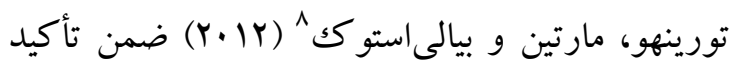
بر فزونى مشكلات يادگيرى دانش آموزان دو زبانه نسبت به دانش آموزان تكك زبانه نشان دادند كه بهبود رشد شناختى و افزايش كنترل شناختى در اين گروه مى تواند تا حدِ زيادى منجر به بهبود عملكرد تحصيلى

${ }^{6}$. Barac \& Bialystok

7. Calvo \& Bialystok

${ }^{8}$. Engel de Abreu, Cruz-Santos, Tourinho, Martin, \& Bialystok مقلdمه دو زبانكى بديدهاى است فراكير و بيّجيده كه در اكثر كشورهاى جهان وجود دارد و بر اساس تعريف فرهنگ لغت آكسفورد دو زبانه به كسى اطلاق مىشود كه كلام خود را به دو زبان مطرح و يا از دو زبان در

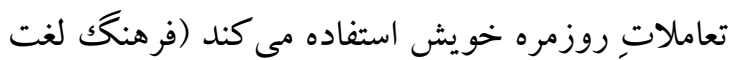

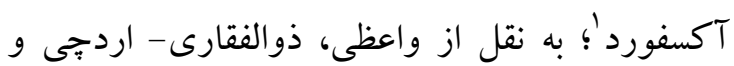

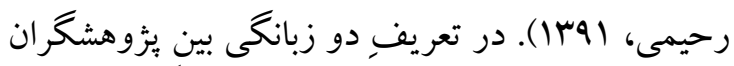
مختلف اتفاق نظر كاملى وجود ندارد، برخى از

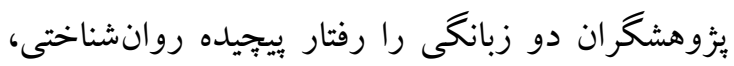
زبانى و اجتماعى - فرهنكى تعريف مى كنند كه ابعادٍ

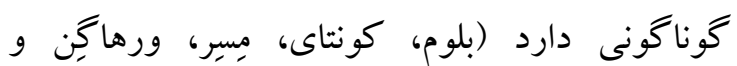

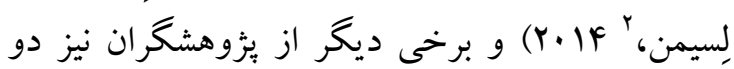
زبانكى را توانش زبانى افراد دوزبانه در دو زبان متفاوت، به ويزّه در بُعدِ كلامى تعريف مى كى كنند،

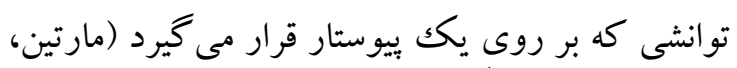

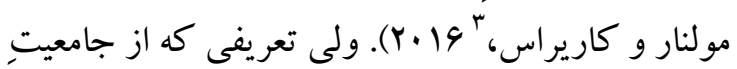

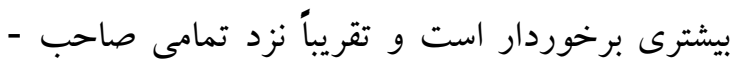

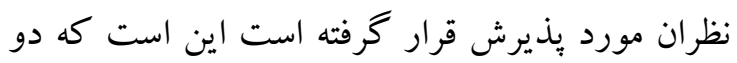

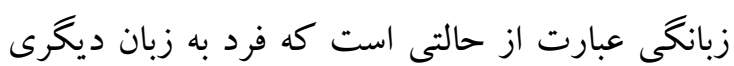
غير از زبان مادرى خويش آموزش مىبيند (فنايى، FAF

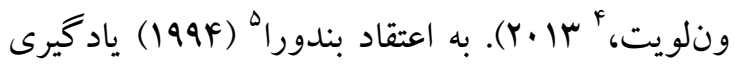
فرايندى است كه فرد از طريق الكو گيرى موضوع مورد نظر را از فردِ الكو اقتباس و در جريان تمرين و و ورئ تكرار در خويشتن درونى مى كند. وى بر اين عقيده

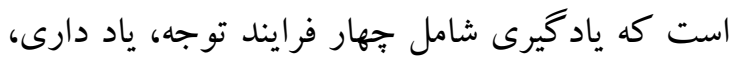
تمرين و تكرار و نهايتاً يادآورى است كه اختلال در

\footnotetext{
Oxford dictionary

Blom, Küntay, Messer, Verhagen, \& Leseman

3. Martin, Molnar, \& Carreiras

4. Friso-van den Bos, van der Ven, Kroesbergen, \& van Luit

5. Bandura
} 
راهبردهاى برنامهريزى، راهبردهاى كنترل و نظارت و

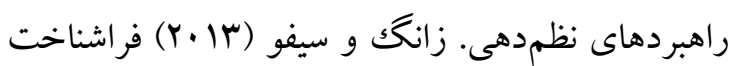
را فرايندهاى كنترل اجرايى شامل توجه، مرور و تمرين، سازماندهى و دستكارى اطلاعات مىدانند كه تسهيل كننده يادگيرى فرد در ابعادِ مختلف تحصيلى است. فراشناخت يكك مفهوم جند وجهى است و اين مفهوم دربر گيرنده دانش و فرآيندهايى است كه

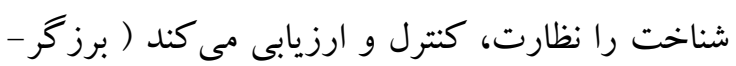
بفرويى و ملايى - بهر امى، سوسا؛ سى لان و هاريوتلو،

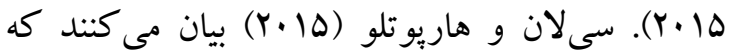
يكى از حوزههايى كه راهبردهاى فراشناختى مى تو اند

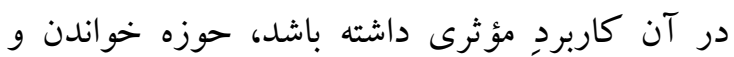
دركِ مطلب است. راهبردهاى فراشناختى خواندن شامل راهبردهاى فراشناختى كلى ' (راهبردهايىاست كه براى تحليل كلى متن به كار مىرود)، راهبردهاى

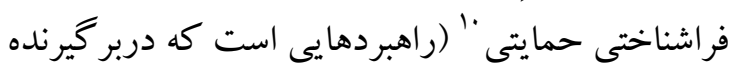

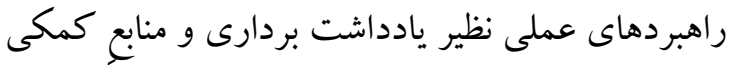
بيرونى است) و راهبردهاى فراشناختى حل مسئله" (راهبردهايى است كه به حل مسائل ناشى از دشوار

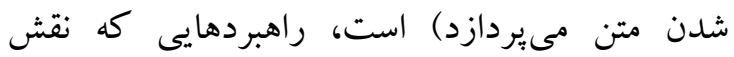
مؤثرى بر بهبود مطالعه و يادگيرى و غلبه بر مشكلات

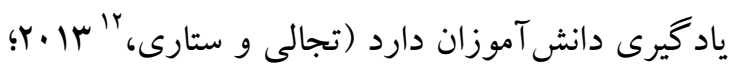

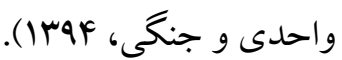
يور - طاهريان و همكاران (سهبr) در يثوهش خويش از اثربخشى راهبردهاى فراشناختى خواندن در حل

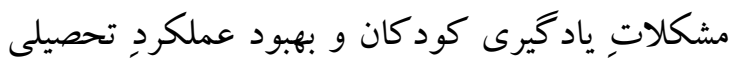
و افزايش ييشرفتِ تحصيلى دانش آموزان خبر مىدهند.

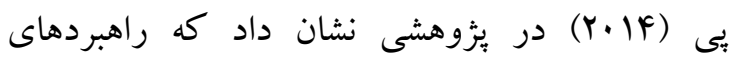
فراشناختى سبب كاهش مشكلات ياد گيرى كود كان و

\footnotetext{
4. Ceylan \& Harputlu

${ }^{5}$. General metacognitive strategies

${ }^{6}$. Supportive metacognitive strategies

7. Metacognitive strategies for problem solving

. Tajalli \& Satari
}

آنها شود. هِرناندِّ، كوستا و هومفريس' (Y.Y.Y)؛

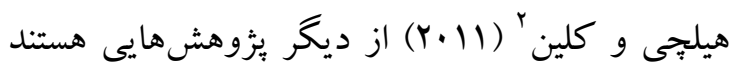
كه بر وجود, مشكلات, يادگيرى نظير مشكل در خواندن، نوشتن و رياضيات در كودكان دو زبانه و فزونى آن نسبت به كود كان تكك زبانه تأكيد مى كنند. يكى از مهمترين عواملى كه بر يادگيرى و عملكردٍ تحصيلى موفقيتآميز و غلبه بر مشكلاتِ يادگيرى تأثير كذار است راهبردهاى فراشناختى ياد گيرى است

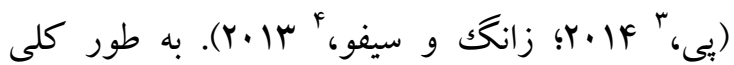
راهبردهاى فراشناختى مجموعه روشهايى است براى

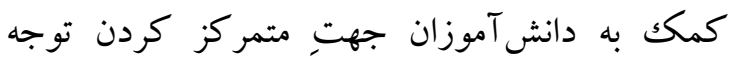
خويش بر مطالب آموزشى با هدف, فهم عميق محتواى آن و ايجاد وبيوند به اطلاعات جديد و قديم و كدگذارى آنها جهت, ذخيره در حافظه (يورطاهريان، خسروى و محمدى- فر، سهبا؛ دى لاياز و

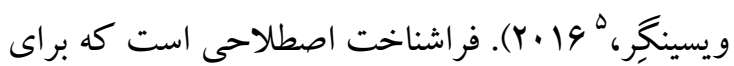
براى اولين بار توسط فلاول (19V9) و به معناى دانش فرد در مورد فر آيندها و توليدات شناختى و فعاليتهاى برى ياد كيرى خود مطرح شد (قحارى و بسنجيده، V ها ·Y). فلاول در رويكرد خويش نسبت به راهبردهاى يادگيرى، اين راهبردها را به دو دستهى كلى نه راهبردهاى شناختى و فراشناختى تقسيم نمود. به اعتقاد

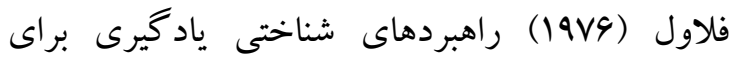
تسهيل يادگيرى و تكميل تكليف به كار مىروند، در حالى كه راهبردهاى فراشناختى به منظور بازبينى اين

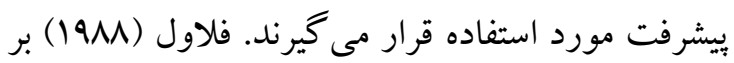
اين عقيده تأكيد مى كند كه راهبردهاى فراشناختى سه راهبرد كلى را در بر مى گيرند كه عبارتاند از

\footnotetext{
9 . Hernández, Costa, \& Humphreys

${ }^{10}$. Hilchey \& Klein

11. Pei

12. Zhang \& Seepho

${ }^{1}$. De La Paz \& Wissinger

2. Flavell

. Ghahari \& Basanjideh
} 
رفتارها را در طول جريان ياد گيرى به فردِ ياد گيرنده

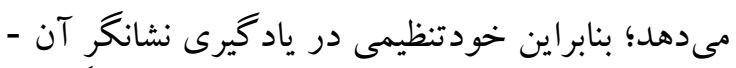

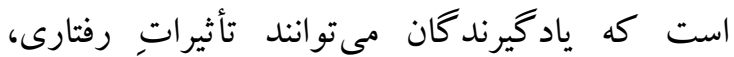
شناختى و انخيزشى خود را بررسى كنند و محيط

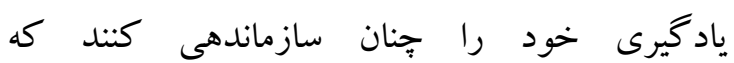

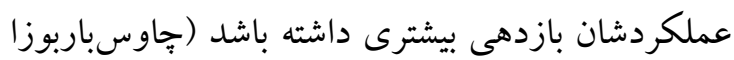

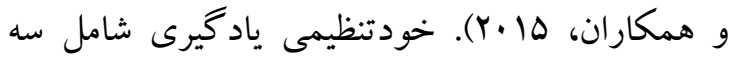
راهبردٍ اصلى است كه عبارتاند از: راهبردهاى

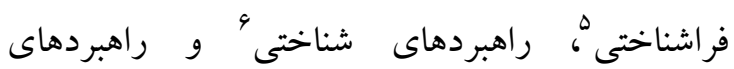

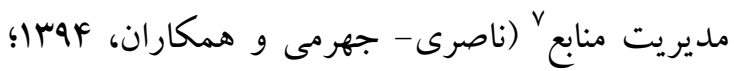

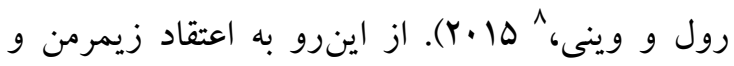

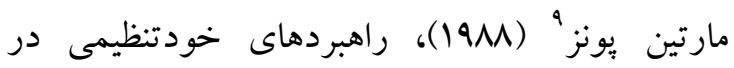
ياد كيرى را شامل خودتنظيمى رفتارى "'، خودتنظيمى لونى

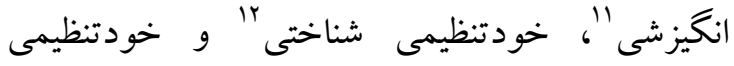
فراشناختى با مىدانند. طرفداران اين ديدگاه بر اين عقيده هستند كه عدم مشار كت فعال ياد گيرند گان در جريان يادگيرى و انتقال مطالب از ياد دهنده به آنها بدون فعاليت ياد گيرند گان ضمن وابسته شدن ياد گيرنده به آنها منجر به كاهش موفقيت, تحصيلى و اختلال در فرايند يادگيرى در ابعادِ مختلف خواندن، نوشتن و و حسابكردن مىشود، لذا بهرهگيرى از لر راهبرد خودتنظيمى يادگيرى مىتواند در كاهش اختلالات و و

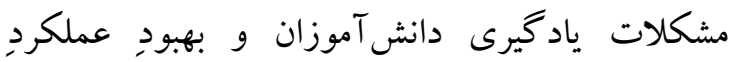
تحصيلى آنها موفقيت آميز عمل كند (زيمرمن،

.$(1919$

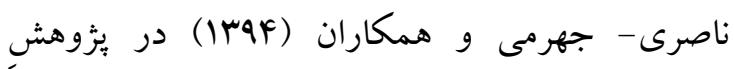
خويش از تأثير راهبردهاى خودتنظيمى در حل

\footnotetext{
2. Metacognitive strategies

3. Cognitive strategies

${ }^{4}$. Resource management strategies

5. Roll \& Winne

6. Zimmerman \& Martinez-Pons

7. Behavioral self-regulation

${ }^{8}$. Motivational Self-regulation

${ }^{9}$. Cognitive self-regulation

${ }^{10}$. Metacognitive self-regulation
}

بهبود عملكرد تحصيلى آنها در ابعادِ مختلف بهويز口ه خواندن و دركِ مطلب شده است. زانگك و سيفو

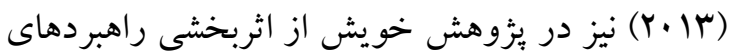
فراشناختى خواندن در رفع نقايص دانش آموزان در

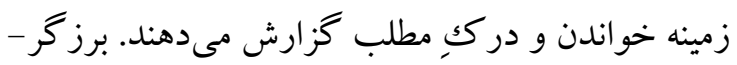

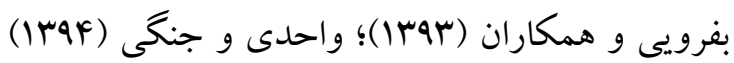
و قحارى و بسنجيده (10) و (Y) و سىلان و هاريوتلو

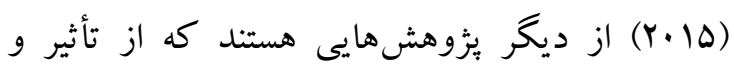
ارتباط راهبردهاى فراشناختى نظير راهبردهاى فراشناختى خواندن در حل مشكلات و نقايص

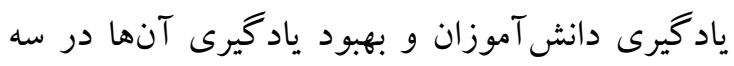
سطح خواندن و دركِِ مطلب، نوشتن و حساب كردن

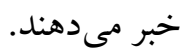
خود تنظيمى يادگيرى يكى ديخر از روشهايى هاست كه تأثير زيادى در بهبود عملكرد تحصيلى افراد و غلبه بر ير

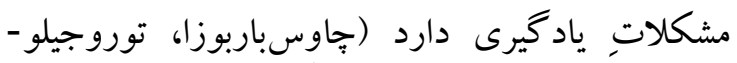

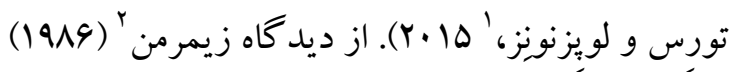
(1919) خود تنظيمى نوعى از ياد گيرى است كه در آن

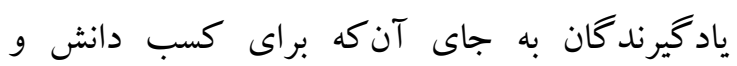

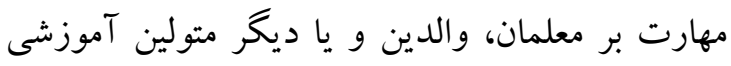
تكيه كنند، شخصاً كوششهاى خود را شروع و هدايت مى كنند. خودتنظيمى يادگيرى توانايى و مهارت

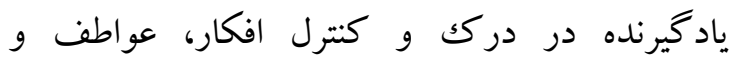
رفتارهاى خويش در طول فرآيندِ يادگيرى است

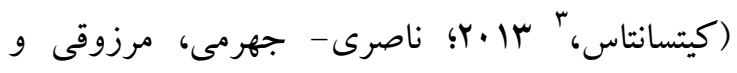

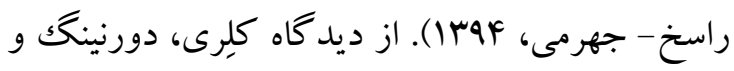

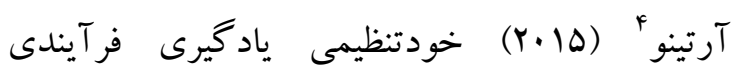
ساختارى و كارآمد است كه امكان برنامهريزى، سازماندهى، ارزيابى و كنترل شناخت، انخيزش و و

\footnotetext{
9. Chaves-Barboza, Trujillo-Torres, \& Lopez-Nunez

${ }^{10}$. Zimmerman

${ }^{11}$. Kitsantas

1. Cleary, Durning, \& Artino
} 
تحصيلى \$\$-\$ه مشغول به تحصيل بودند. نمونه يثزوهش شامل •M دانش آموز دختر و يسر دو زبانه بود كه با توجه به تعداد خرده مقياسها و بر اساس مدل

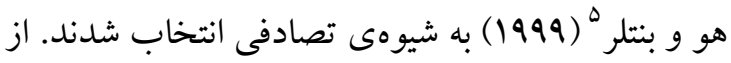
از بين مدارس متوسطهى موجود در شهرستان سنندج، مدارس منطقه يكك اين شهرستان بهصورت تصادفى انتخاب شد و از بين مدارس منطقه يكك تعداد هـ مدرسه (r مدرسه يسرانه و Y مدرسه دخترانه) به شيوهى تصادفى انتخاب شدند و بعد از روشن شدن هدف يزّوهش و جلب نظر و همكارى آنها يرسشنامهاى

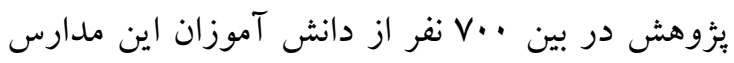
يخش شد كه تعداد . . ه نفر از اين دانش آموزان يرسشنامها را بهصورت كامل تكميل نموده و تحويل دادند و بهمنظور آزمون فرضيههاى يُزوهش، دادههاى

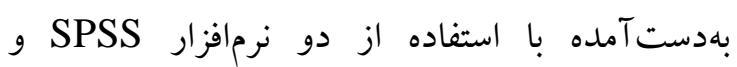
AMOS

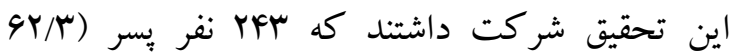

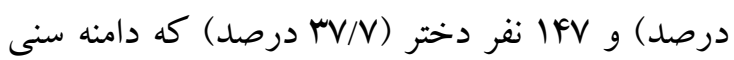
آنها بين أI تا 19 سال متغير بود و ميانگين سنى آنها

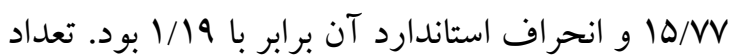
TMF درصد)، نفر پايه سوم متوسطه (N/Y درصد) و ا9 نفر پِايه جهارم متوسطه (ه/9 إدصد) بودند و تعداد TVD نفر از والدينى كه يرسشنامه مشكلات ياد گيرى دانش آموزان

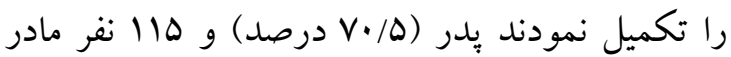

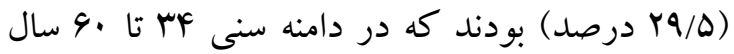
قرار داشتند و ميانگين سنى آنها FF/FD و انحراف

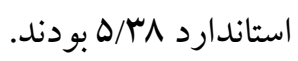

\footnotetext{
1. Hu \& Bentler
}

مشكلات ياد گيرى دانش آموزان در سه بُعدِِ خواندن،

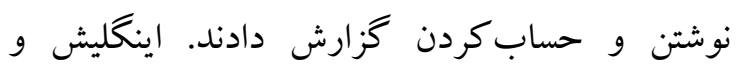

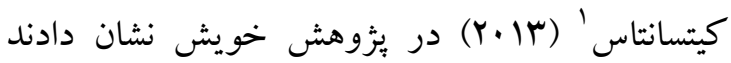
دانش آموزانى كه از راهبردهاى خودتنظيمى در جريان

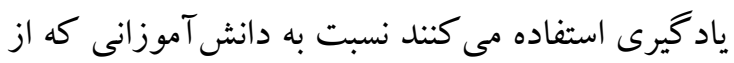
اين راهبردها استفاده نمى كنند مشكلاتِ كمترى در زمينه ياد گيرى دارند و عملكردِ تحصيلى شان نيز بهتر و موفقتر است. محمودى، كلانترى و قسلانى ب (Y. Y Y)؛

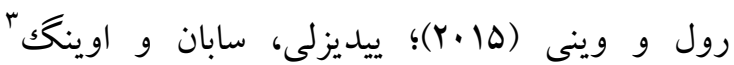

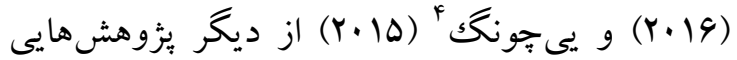
هستند كه از اثربخشى راهبردهاى خودتنظيمى در حل

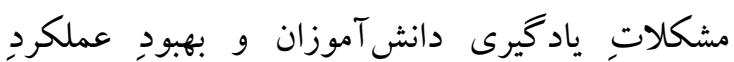
تحصيلى آنها خبر مىدهند و بيان مى كنند دانش آموزانى كه از اين راهبردها در جريان يادكيرى استفاده

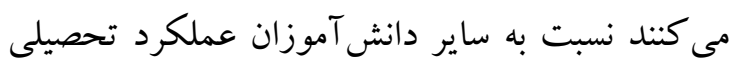

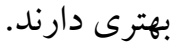
مطالب بيشين به خوبى فزونى مشكلات, يادگيرى كود كان دو زبانه را آشكار و همجنين رابطه راهبر دهاى فراشناختى خواندن و خودتنظيمى يادگيرى را در حل

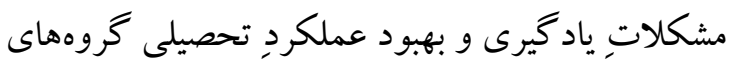
مختلفى از ياد گيرند گان بهويزه دانش آموزان را بهرد آشكار مى كند، لذا در اين هُزوهش به بر برسى ارتباطِ خود تنظيمى ياد گيرى و راهبردهاى فراشناختى خواندن با مشكلات, يادگيرى به زبان دوم در دانش آموزان دو

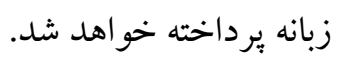
يخزوهش حاضر از نوع توصيفى - همبستكى بود. جامعه

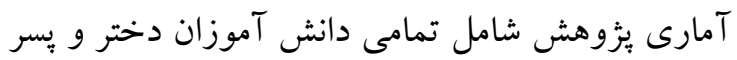
دو زبانهُ متوسطه شهرستان سنندج بود كه در سال

\footnotetext{
${ }^{11}$. English \& Kitsantas

${ }^{12}$. Mahmoodi, Kalantari, \& Ghaslani

13. Yidizlı, Saban, \& Ewing

14. Yi Chung
} 
فراشناختى خواندن را توصيف مى كند. سه دسته از

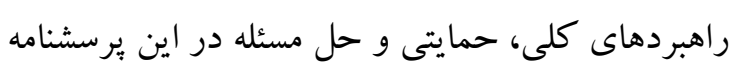

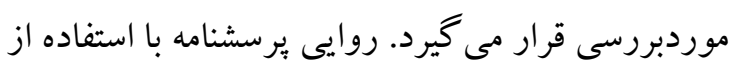

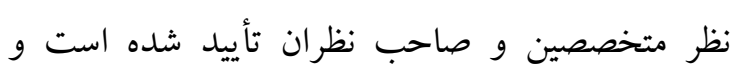

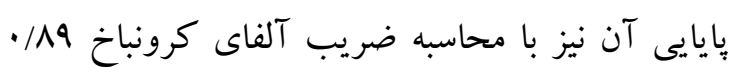

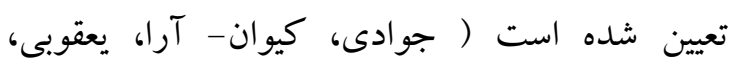

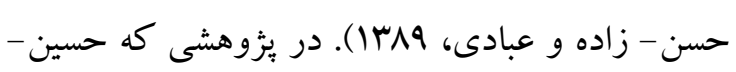
جارى، سماوى و كردستانى (IMNA) انجام داده اند

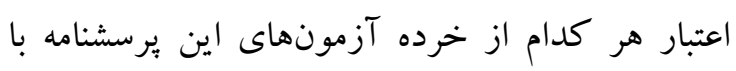
استفاده از روش آلفاى كرونباخ براى راهبردهاى

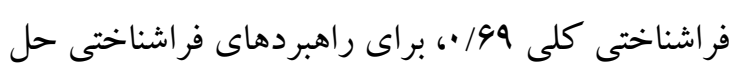
مسئله سو/ • و براى راهبردهاى فراشناختى حمايتى برابر

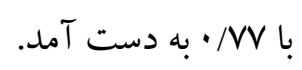

\section{برسشنامه مشكلات يادكيرى كلورادوه (CLDQ) به اين}

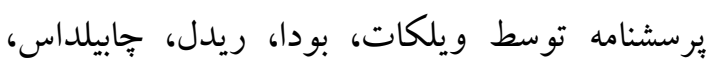

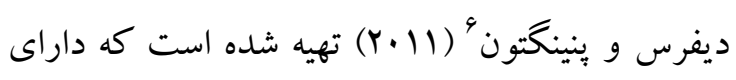

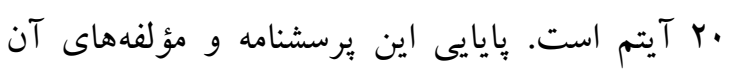

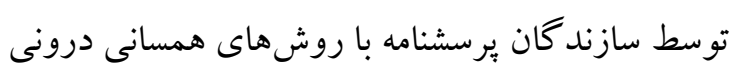

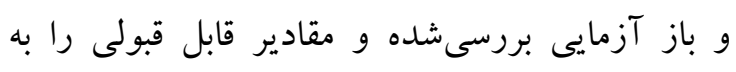

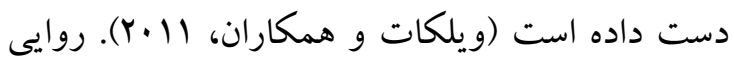
تفكيكى و روايى سازه برسشنامه مذكور در حد حد

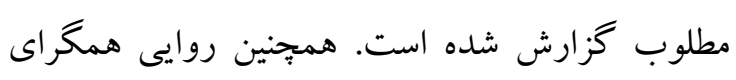
مؤلفه هاى اين ويرسشنامه با برسشنامه ييشرفت تحصيلى

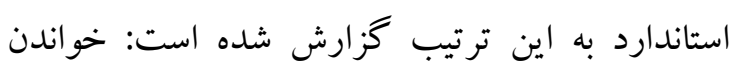

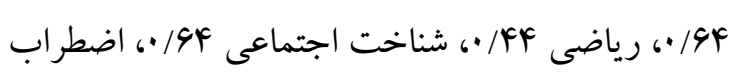
اجتماعى 194/ ، و فضايى •ب/· (ويلكات و همكاران،

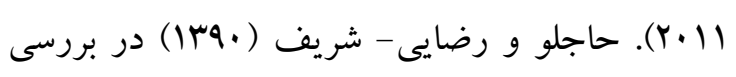
بايايى اين يرسشنامه از دو روش همسانى درونى و باز آزمايى استفاده كردند. همسانى درونى كل و و خرده مقياسهاى آن از طريق محاسبه آلفاى كرونباخ به اين

3 . Colorado Learning Difficulties Questionnaire 4. Willcutt, Boada, Riddle, Chhabildas, DeFries, Pennington

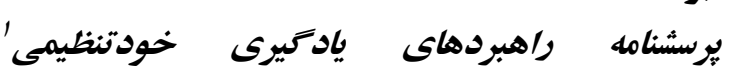
(MSLQ) انخيزشى و راهبردهاى يادگيرى خودتنظيمى است و

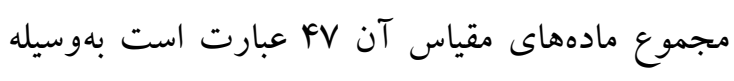

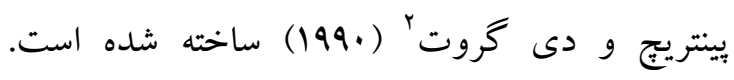
مقياس باورهاى انخيزشى شامل سه خروده آنمون

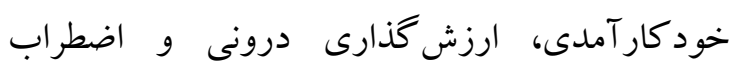
امتحان است. مقياس ياد كيرى خودتنظيمى داراى دو آرون خرده آزمون راهبردهاى شناختى و فراشناختى است.

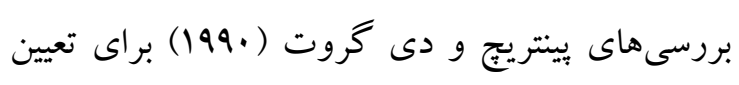

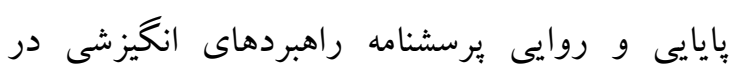

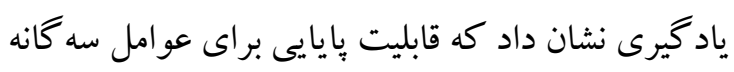

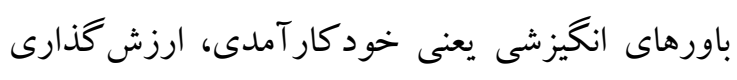

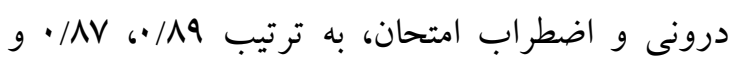
خDD • و براى دو عامل مقياس راهبردهاى يادگيرى

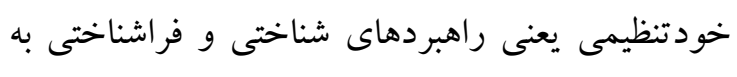

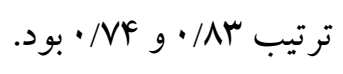
رامشه و حسينى- نسب (IrVq) در ايران اعتبار اين آزمون را بررسى كردند كه نتايج به دست آمده آلفاى

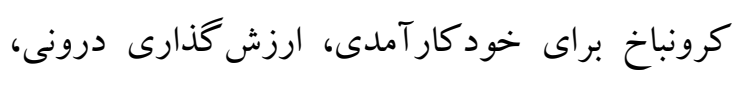

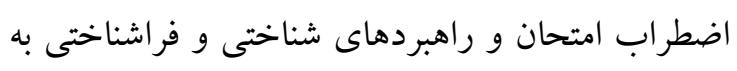

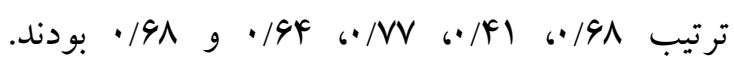
همجينين البرزى و سامانى (IrVNA) براى به دست آوردن

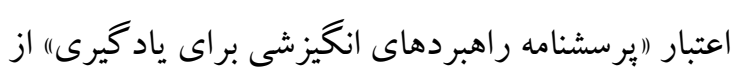

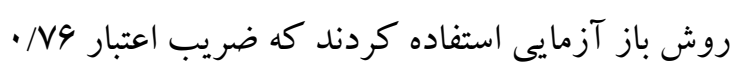
به دست آمد. برسشنامه آكاهى فراشناختى از راهبردهاى خواندن"

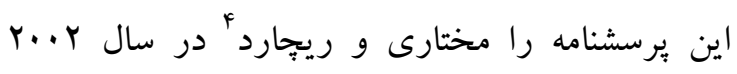

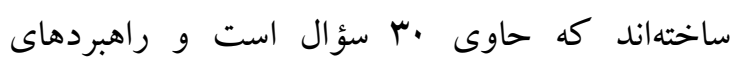

\footnotetext{
2. Motivated Strategies for Learning Questionnaire

. Pintrich \& de Groot

. Metacognitive awareness of reading strategies

. Mokhtari \& Reichard
} 
مشكلات ياد گيرى كلورادو نيز مورد تأييد قرار گرفت

(حاجلو و رضايى-شريف، •وr1).

يافته ها

بخش اول نتايج حاصل از يثوهش در جدول شماره (1) نشان مىدهد كه رابطهى منفى و معنادارى بين راهبردهاى خودتنظيمى يادگيرى و و راهبردهاى فر اشناختى خو اندن با مشكلات يادكيرى دانش آموزان

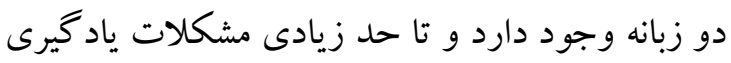
دانش آموزان را ييشبينى مى كند.
ترتيب گزارش شده است: خواندن MA/•، رياضى

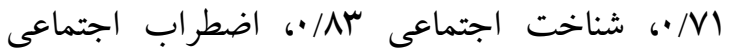

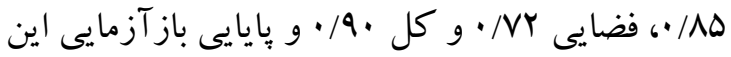

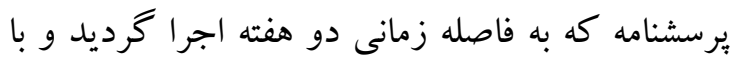
استفاده از روش همبستكى ضريب بايايى آزمون - باز آزمون به قرار زير به دست آمد: خواندن سه/ •، رياضى /AV AF/A •، فضايى AY/• و كل \&F/•. روايى سازه برسشنامه

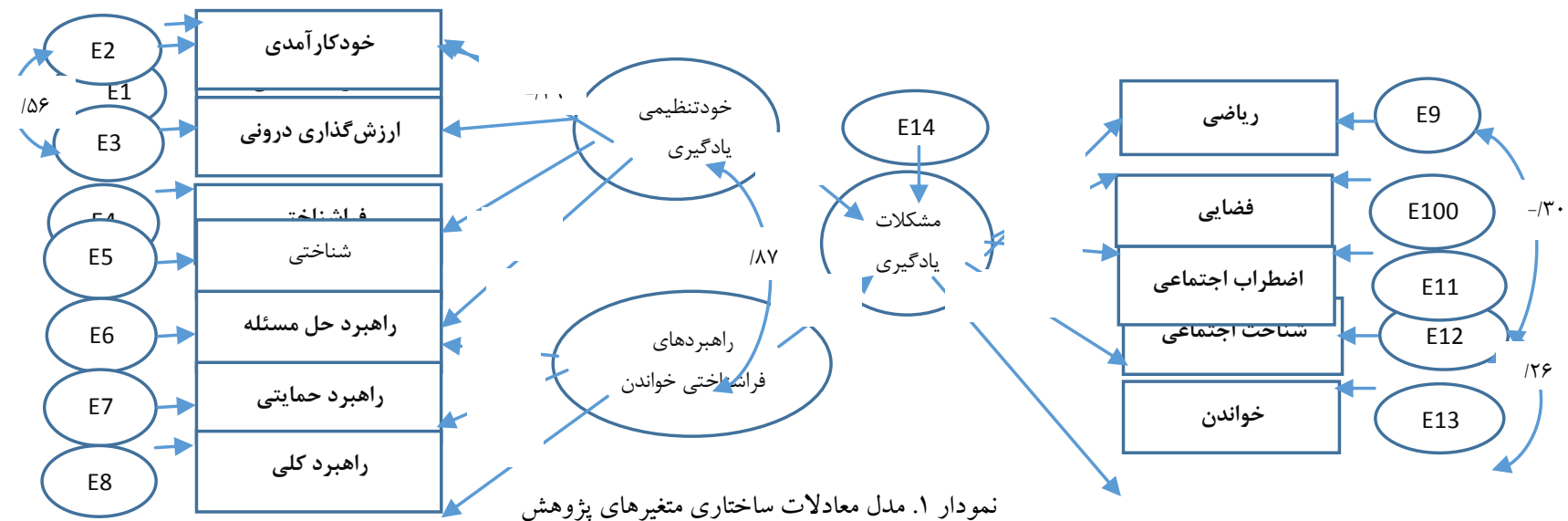

خودتنيمى ياد گيرى نيز همبستگى بالايى (AV/•) ديده مى شود؛ بنابر اين مىتوان كفت تر كيبى از اين دو متغير مشكلات يادگيرى را بهتر بيشبينى مى كند. از بين خرده مقياسهاى راهبردهاى فراشناختى خواندن، خودتنظيمى ياد گيرى و مشكلات ياد گيرى به ترتيب،

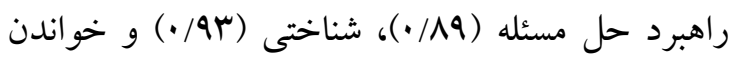
(·NA)
اين نمودار نشان مىدهد كه راهبردهاى فراشناختى خواندن و خودتنظيمى ياد گيرى بر مشكلات ياد گيرى

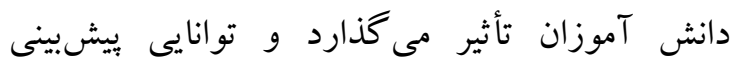
مشكلات ياد گيرى دانش آموزان را دارد. مطابق نمودار بالا راهبردهاى فراشناختى خواندن (FF (•-) و خودتنظيمى ياد گيرى (\$9/.-) بر مشكلات يادگيرى

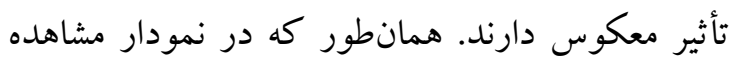

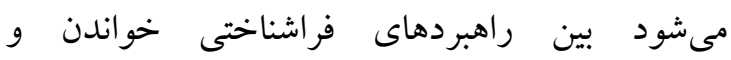

جدول ז. شاخصهاى برازش مدل تحقيق

\begin{tabular}{|c|c|c|c|c|c|c|c|c|c|c|c|}
\hline $\begin{array}{r}\text { (RM } \\
\text { SEA) } \\
\end{array}$ & (NFI) & (TLI) & (CFI) & (IFI) & (GFI) & (AGFI) & (RMR) & (CMIN/DF) & DF & CMIN & شاخص \\
\hline$\cdot / \cdot v$ & $\cdot / 9 F$ & $\cdot / 9 F$ &.$/ 99$ &.$/ 94$ & $\cdot / 9 r$ & $\cdot / \mathrm{MA}$ & $1 / 19$ & r/ץ & $\Delta Q$ & $199 / 1$. & مقدار \\
\hline مطلوب & مطلوب & مطلوب & مطلوب & مطلوب & مطلوب & مطلوب & ضعيف & مطلوب & مطلوب & مطلوب & بعيت \\
\hline
\end{tabular}


عبارتى دادههاى حاصل از تحقيق، مدل نظرى تحقيق را حمايت و تأييد مى كنند.
نتايج جدول شماره (Y)، گوياى اين مطلب است كه تحقيق حاضر داراى برازش مطلوبى است و ساختار

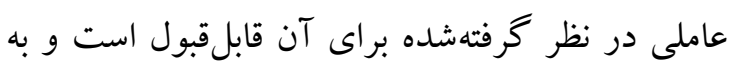

جدول r. بر آورد استاندارد و غيراستاندارد متغيرهاى ثئوهش

\begin{tabular}{|c|c|c|c|c|c|}
\hline معنى دارى & بحر انى & استاندارد خطاى & غير استاندارد & ضريب استاندارد & 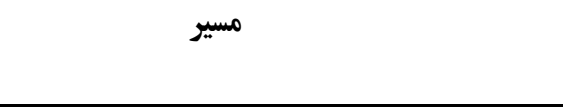 \\
\hline ***** & $-0 / .9 \Delta$ & $\cdot / \cdot r q$ & $-/ 199$ & $-\cdot / \Delta 9$ & خودتنظيمى ياد كيرى † مشكلات يادگيرى \\
\hline$\cdot / \cdot r$ & $-Y / Y \cdot Q$ & .1 .94 & $-/ 1 \mu \wedge$ & $-\cdot / Y F$ & راهبردهاى فراشناختى خواندن > مشكلات ياد گيرى \\
\hline 粆档 & $\| / N 1 r$ & f/.rt & FV/rYA & $\cdot / \Lambda \mathrm{V}$ & خودتنظيمى ياد كيرى † کراهبردهاى فراشناختى خو اندن \\
\hline 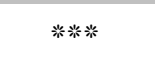 & $-1 \cdot /$ IV & 每 & $-/$ MY & $-\cdot / 49$ & خودتنظيمى يادگيرى > اضطراب امتحان \\
\hline ***** & rr/arr & $\cdot / \cdot \uparrow \Lambda$ & $19 \mathrm{~V}$ & $\cdot / A F$ & خو تنظيمى ياد يرى † خود كار آمدى \\
\hline 光光粠 & $r \cdot / r ৭ 9$ &.$/ 19$ & $/ 419$ & $\cdot / \mathrm{VV}$ & خودتنظيمى يادگيرى > ارزش گذارى درونى \\
\hline \multirow[t]{3}{*}{ 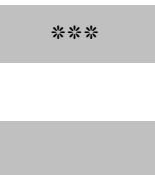 } & YI//9V & $\%$ & IFAF & $\cdot /$ १ & خودتنظيمى يادگيرى † فراشناختى \\
\hline & & & $1 / \cdots$ & $\cdot / 94$ & خودتنظيمى ياد گيرى ك شناختى \\
\hline & & & $1 / \cdots$ & $\cdot / 19$ & راهبردهاى فراشناختى خواندن × راهبرد حل مسئله \\
\hline 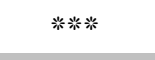 & $Y F / \cdot I V$ & $\cdot / \cdot F$ & 1994 & $\cdot / \mathrm{AV}$ & راهبردهاى فراشناختى خو اندن × راهبرد حمايتى \\
\hline 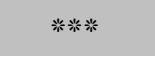 & $r r / \Delta q F$ & $\cdot / \cdot \Delta \Lambda$ & I/rVD & $\cdot / \mathrm{AV}$ & راهبردهاى فراشناختى خواندن × راهبرد كلى \\
\hline 粆䉼标 & Ir/VG. & $.1 .+9$ & $19 \mathrm{VI}$ & $\cdot / V r$ & مشكلات يادگيرى † رياضى \\
\hline 米米米 & $\mid F / G F V$ &.$/ \Delta F$ & /VaV & $\cdot / V^{F}$ & مشكلات ياد كيرى ك فضايى \\
\hline 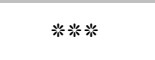 & Ir/AY. & $\cdot / \cdot F \Delta$ & 1919 & $\cdot / N r$ & مشكلات ياد گيرى < اضطراب اجتماعى \\
\hline \multirow[t]{2}{*}{ 粪㫧光 } & $10 / .90$ & .1 .49 & MEY & $\cdot 194$ & مشكلات يادگيرى ک شناخت اجتماعى \\
\hline & & & $1 / \cdot \cdot$ & $\cdot / \mathrm{V} \wedge$ & مشكلات ياد گيرى \\
\hline 米米米 & V/AAr & $\cdot / V \cdot V$ & $\Delta / \Delta V$ & $\cdot / \Delta 9$ & $\mathrm{e} 2 \leftrightarrow \mathrm{e} 3$ \\
\hline 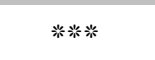 & $-F / g M F$ & $\cdot / T V \Delta$ & $-1 / Y V F$ & $-\cdot / \mu$ & $\mathrm{e} 9 \leftrightarrow \mathrm{e} 11$ \\
\hline 类㫧米 & r/AYG & $\cdot / \Delta \cdot V$ & 1/94q & $\cdot / Y^{4}$ & $\mathrm{e} 12 \leftrightarrow \mathrm{e} 13$ \\
\hline
\end{tabular}

ياد گيرى فضايی، خو اندن، رياضى، اضطراب اجتماعى و شناخت اجتماعى) دارند.

\section{بحث و نتيجه كيرى}

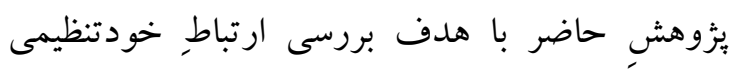
ياد گيرى و راهبردهاى فراشناختى خواندن با مشكلات ياد گيرى به زبان دوم در دانش آموزان دو زبانه انجام

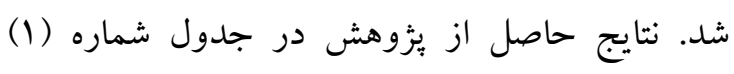
نشانداد كه رابطهى منفى و معنادارى بين راهبردهاى
نتايج حاصل از يزوهش در جدول شماره (r) بيانگر اين

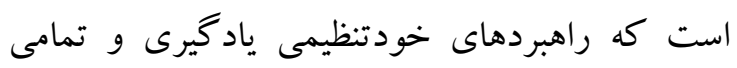
مؤلفههاى آن (ارزش گذارى درونى، خود كار آمدى، راهبردهاى شناختى و فراشناختى) به استثناى مؤلفهى اضطراب امتحان كه داراى رابطه مثبت با مشكلات وردئ

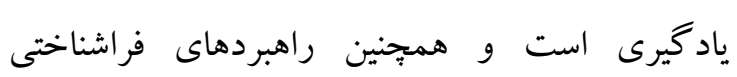
خواندن و تمامى مؤلفههاى آن (راهبرد حل مسئله،

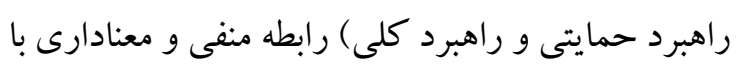

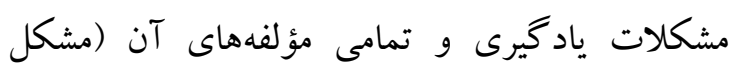




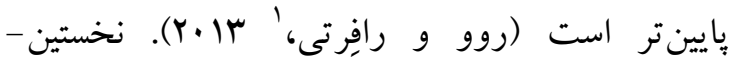

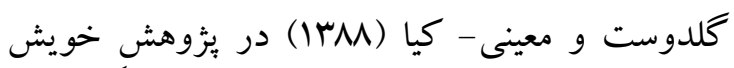
كزارش كردند كه راهبردهاى خودتنظيمى ياد گيرى در بهبودِ انخيزش و عملكردٍ تحصيلى فرد و و كاهش

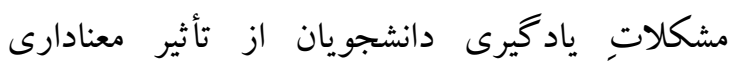
برخوردار است. ناصرى- جهرمى، مرزوقى و راسخجهرمى (IM IF) نيز در ئزوهش خويش از راهبردهاى

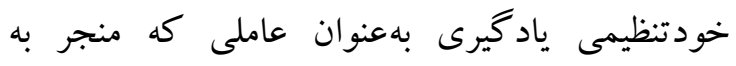
افزايش باورهاى انخيزشى مى شوند يادكردند و نشان دادند كه به كارگيرى اين مهارتها سطح موفقيت تحصيلى افراد را تا حدِ زيادى بالا مىبرد. ساير يزوهشهايى كه اثربخشى راهبردهاى خحودتنظيمى

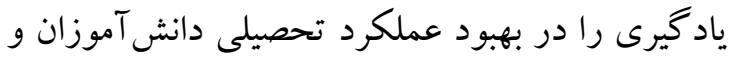
كاهش احتمال بروز مشكلات يادگيرى در آنها مورد تأكيد قرار دادند مىتوان به بثزوششهاى محمودى و

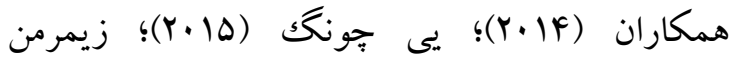
(1919) و زيمرمن و مارتين يونز (1941) اشاره كرد. در تبيين اين يافته مىتوان كفت خودتنظيمى ياد گيرى

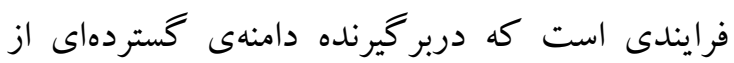
راهبردهاى شناختى و فراشناختى، ارزش كذارى درونى، خود كار آمدى و تو انايى كنترل اضطراب همر اه است و افرادى كه از آن بهره مى گيرند با انگيزه و و خودكارآمدى زيادى در جريان يادگيرى خويش مشار كت مى كنند و بدين شكل ميز ان يادكيرى خويش

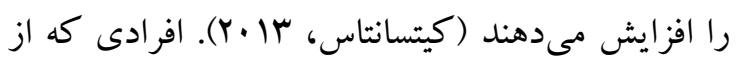
راهبردهاى خودتنظيمى ياد گيرى استفاده مى كنتد

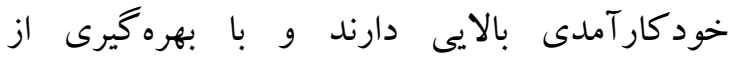
راهبردهاى شناختى و فراشناختى به برنامهريزى دقيق،

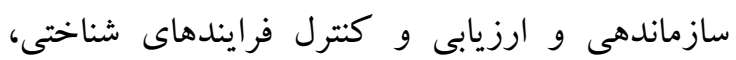
انخيزشى و رفتارى در طول ياد گيرى مى يردازند و بدين شكل سطح يادگيرى خويشتن را افزايش مىدهند و وريري
خود تنظيمى ياد گيرى و راهبردهاى فراشناختى خواندن با مشكلات, ياديرى دانش آموزان دو زبانه وجود داردي ودئي و تا حدِ زيادى مشكلات ياد گيرى دانش آموزان را

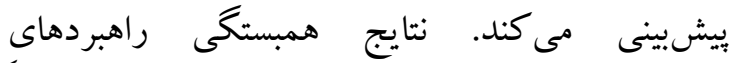

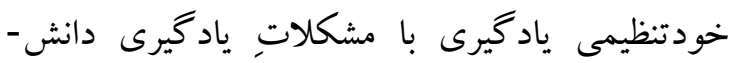

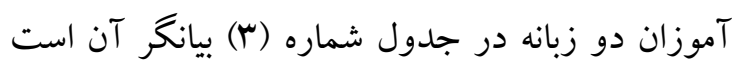
كه راهبردهاى خودتنظيمى ياد گيرى و تمامى مؤلفه-

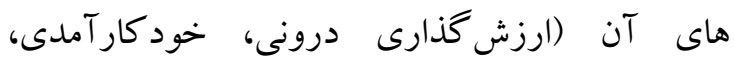
راهبردهاى شناختى و فراشناختى) به استثناى مؤلفهى اضطراب امتحان كه داراى رابطهى مثبت با مشكلات ياد گيرى است، رابطه منفى و معنادارى با مشكلات

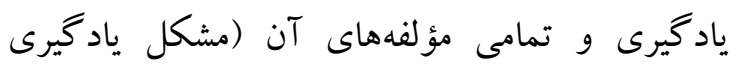
فضايى، خواندن، رياضى، اضطراب اجتماعى و شناخت اجتماعى) دارند. به عبارت ديخر نتايج حاصل از جدول شماره (T) نشان داد دانش آموزانى كه از راهبردهاى خودتنظيمى يادگيرى برخوردار هستند و در فرايندِ يادگيرى خويش از آنها استفاده مى كنند مشكلات ياد گيرى كمترى دارند و عملكردِ تحصيلى آنها نسبت

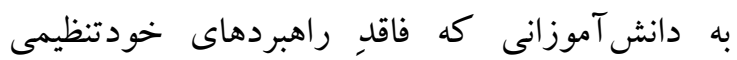
ياد گيرى هستند و در جريان يادگيرى خويش از آنها استفادهاى نمى كنند بهتر است. راهبردهاى خودتنظيمى ياد گيرى با سازماندهى كردن

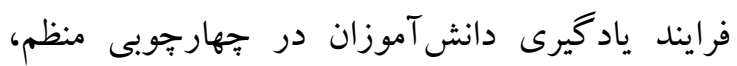
منجر به افزايش سطح انخيزش تحصيلى دانش آموزان و

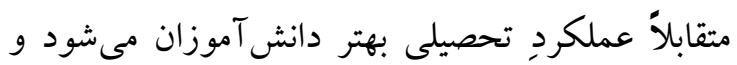

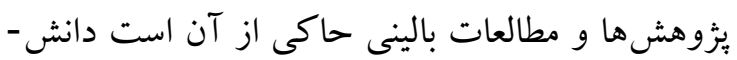
آموزانى كه از راهبردهاى خودتنظيمى يادگيرى برخوردار هستند نسبت به ساير دانش آموزان كه از اين

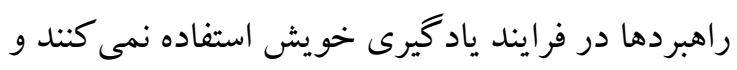
از داشتن آنها محروم هستند عملكردِ تحصيلى بهترى دارند و سطح مشكلات, يادگيرى آنها نيز به مراتب

${ }^{1}$. Rowe \& Rafferty 
مهارتهاى حل مسئله، مهارتهاى فراشناختى و و مان

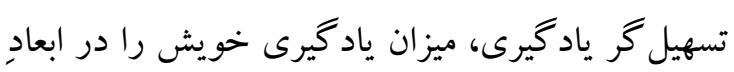

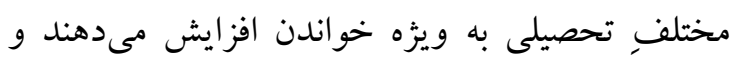
كمتر احتمال دارد در اين بعد دجار مشكل و و اختلال شوند. تجالى و ستارى (سوبr|) بيان كردند راهبردهاى

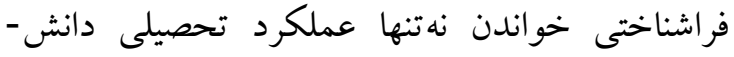

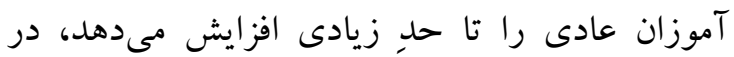
بهبود عملكرد تحصيلى دانش آموزان مبتلا به اختلال توجه نيز از عملكردٍ مطلوبى برخوردار است و و

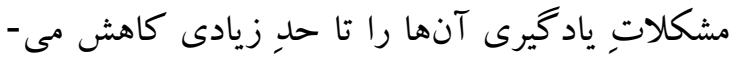

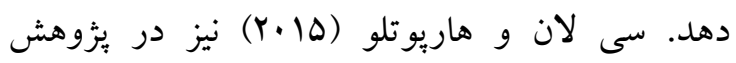
خويش از تأثير معنادار راهبردهاى فراشناختى خواندن در بهبود عملكرد تحصيلى دانش آموزان خبر دادند و بيانكردند كه اين مهارتها منجر به تسهيل جريان

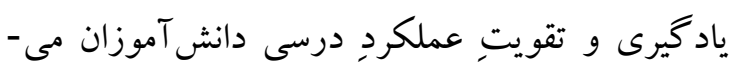

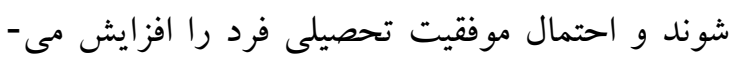

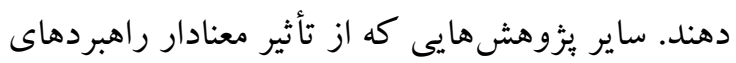
فراشناختى خواندن بر عملكرد تحصيلى دانش آموزان

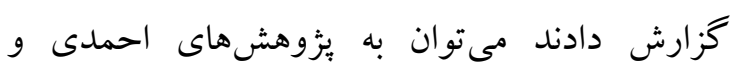

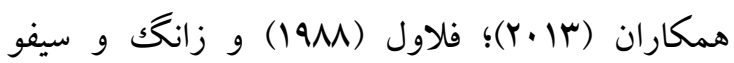

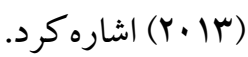
در تبيين اين نتيجه مىتوان گفت افرادى كه از اين

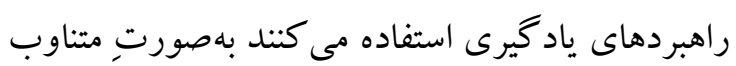
به تفسير متن مى بردازند و آن را در جريان ذهنى خويش تجزيه و تحليل مى كنند و همجنين با تكيه بر اصول علمى يادگيرى نظير يادداشتبردارى و بهره-

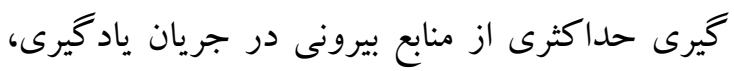

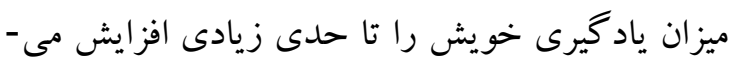
دهند و همجِنين در صورت بروز هر گُونه اختلال در

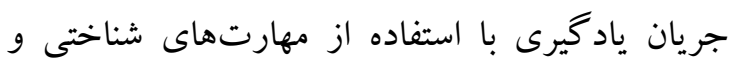
فراشناختى حل مسئله، رفع مشكل ايجاد شده را تسهيل

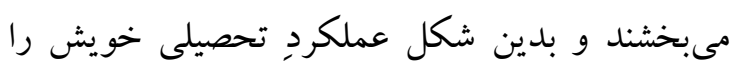

كمتر احتمال دارد به مشكلات ياد گيرى دجار شوند و

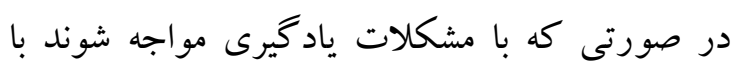
بهرهگيرى از راهبردها و توانمندى هاى شناختى و و

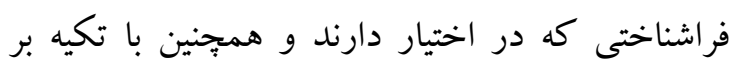
احساس توانمندى درونى خويش به شيوهاى خلاقانه و توأم با پشتكار در جهتِ غلبه بر مشكل ايجاد شده گام بر مىدارند (كِلرى و همكاران، ها •r). نتايج همبستخى راهبردهاى فراشناختى خواندن با فمان مشكلات يادگيرى دانش آموزان در جدول شماره (r) نشانداد كه راهبردهاى فراشناختى خو اندن و تمامى ئى مؤلفههاى آن (راهبرد حل مسئله، راهبرد حمايتى و راهبرد كلى) رابطه منفى و معنادارى با مشكلات ياد گيرى دانش آموزان و تمامى مؤلفههاى آن (مشكل

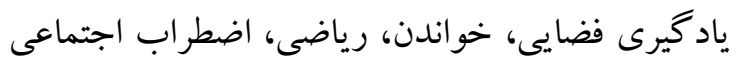
و شناخت اجتماعى) دارد. بهعبارتديخر نتايج حاصل از جدول شماره (r) نشان داد دانش آموزانى كه از راهبردهاى فراشناختى خواندن برخوردار هستند و در فرايند يادگيرى خويش از آنها استفاده مى كنند،

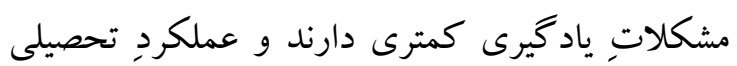
آنها نسبت به دانش آموزانى كه فاقد ر راهبردهاى فراشناختى خو اندن هستند و در جريان ياد گيرى خويش

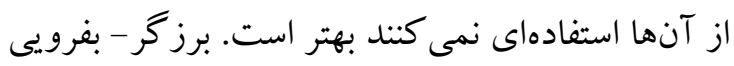
و همكاران (سوسا) در بزّوهش خويش نشان دادند ياد گيرند گانى كه از راهبردهاى فراشناختى برخوردار هستند و توانايى بهره گيرى از آن را در موقعيتهاى مختلف يادگيرى دارند نسبت به ساير ياد گيرند گان انخيزش و عملكرد تحصيلى بهترى دارند و از مشكلات ياد كيرى كمترى برخوردار هستند.

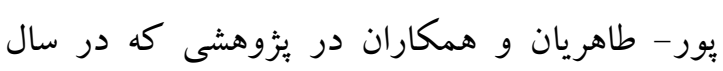

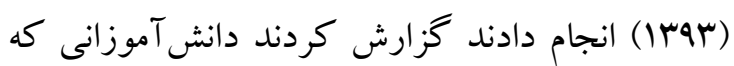
از راهبردهاى فراشناختى خواندن در جريان يادگيرى خويش استفاده مى كنند با بهره گيرى از انواع مختلفى از حرني 


$$
\text { (ابتدايى و متوسطظ بر روى دانش آموزانِ مقاطع مختلف تحصيلى مورد بررسى و مقايسه قرار گيرد. }
$$

\section{References}

Alborzi, S., Samani, S. (1999). Comparing motivaltional belifs and self regulatory leaming strategies in students, Shiraz. Joumal of Social and Humanestic Sciences, 29(15): 1-18. (in persian)

Bandura, A. (1994). Social cognitive theory of mass communication. In. J. Bryant \& D. Zillmann (eds.), Media effects: Advances in theory and research, UK: Routledge.

Barac, R, \& Bialystok, E. (2011). Cognitive development of bilingual children. Language Teaching, 44 (1), 36-54.

BarezegarBarfooei, K., BarzegarBarfooei, M. MollaeeBahrami, Y. (2015). The role of goal orientation and metacognitive reading strategies in predicting academic motivation of male students of Yazd Farhangian University, Research in School and Virtual Learning, 2(5): 27-42. (in persian)

Blom, E, Küntay, A. C, Messer, M, Verhagen, J, \& Leseman, P. (2014). The benefits of being bilingual: Working memory in bilingual Turkish-Dutch children. Journal of Experimental Child Psychology, 128, 105119.

Calvo, A, \& Bialystok, E. (2014). Independent effects of bilingualism and socioeconomic status on language ability and executive functioning. Cognition, 130(3), 278-288.

Ceylan, E, \& Harputlu, L. (2015). Metacognition in reading comprehension. The Literacy Trek,1 (1), 5-14

Chaves-Barboza, E, Trujillo-Torres, J. M, \& LopezNunez, J. A. (2015). Accomplishments in leaming self-regulation in personal environments. Creative Education, 6(11), 1108-1120.

Cleary, T. J, Duming, S. J, \& Artino, A. R, Jr. (2016). Microanalytic assessment of self-regulated leaming during clinical reasoning tasks: recent developments and next steps. Academic Medicine, 9(11), 1516-1521.
فزونى مىبخشند (فلاول، 1911). از طرف ديخر افرادى كه از اين راهبردها در جريان ياد گيرى بهره نمى گيرند بيشتر احتمال دارد با گستردهاى از مشكلات يادگيرى در ابعادِ مختلف خواندن، نوشتن و حساب كردن مواجه شوند، زيرا فعاليتهاى ياد گيرى آنها با نظم و تسلسل منطقى و دقيقى همراه نيست و نبودِ مهارتهاى حل مسئله و ناتوانى در بهره گيرى از مهارتهاى شناختى و ونه فراشناختى و روشهاى علمى يادگيرى، بروز اين مشكلات را افزايش و امكان حل آن را تا حد زيادى

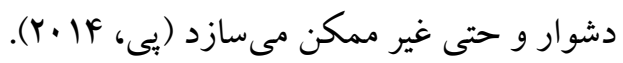
بهور كلى يافتهاى حاصل از يزوهش نشان مان داد كه

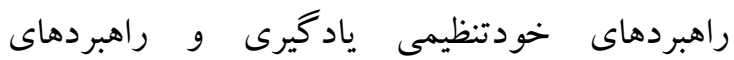
فراشناختى خواندن رابطه منفى و معنادارى با مشكلات ياد گيرى دارند و دانش آموزانى كه از اين راهبردها در جريان ياد گيرى خويش استفاده مى كنند كمتر احتمال دارد دجار مشكلات يادگيرى شوند. اين يافته ضا ضمنِ

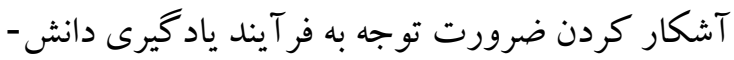
آموزان دو زبانه و مشكلات بيشروى آنها در جريان

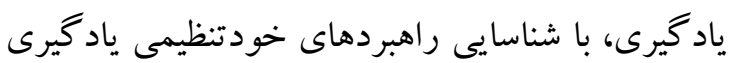
و راهبردهاى فراشناختى خواندن به عنوان عوامل مؤثر بر بهبود عملكرد تحصيلى دانش آموزان دو زبانه و كاهش مشكلات يادگيرى آنها، مىتواند در تدوين برنامهاى آموزشى و فرايندهاى ياد كيرى اين دانش آموزان توسط افراد فعال در اين حوزه به ويزه والدين و

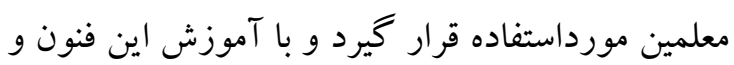
راهبردها به اين دانشآموزان احتمال بروز مشكلات يادگيرى را در آنها كاهش دهند و عملكرد تحصيلى آنها را با موفقيت بيشترى همراه سازند. از جمله محدوديتهاى اين يزوهش مىتوان به محدود بودن نمونه به دانش آموزان مقطع متوسطه تحصيلى اشاره

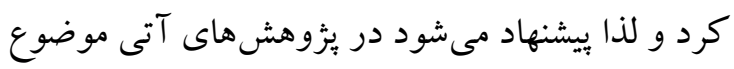


De La Paz, S., \& Wissinger, D. R. (2016). Improving the historical knowledge and writing of students with or at risk for LD. Journal of Learning Disabilities, $O(0)$.

EngeldeAbreu, P. M. J., Cruz-Santos, A., Tourinho, C. J, Martin, R., \& Bialystok, E. (2012). Bilingualism enriches the poor. enhanced cognitive control in low-income minority children. Psychological Science, 23(11), 1364-1371.

English, M. C, \& Kitsantas, A. (2013). Supporting student self-regulated learning in problemand project-based leaming. Interdisciplinary Joumal of Problem-Based Learning, 7(2), 128-150.

Faiazibarzini, L. (2010). The relationship between bilingualing speech disabilities, Journal of Exceptional Education, 102(1): 62-67. (in persian)

Fanaii, M. (2004). Problems of bilingual studing, Dilmac, 1(13): 20-29. (in persian)

Flavell, J. H. (1976). Metacognitive aspects of problem solving. In L. B. Resnick (Ed.), The Nature of Intelligence (pp. 231-235). Hillsdale, NJ: Earlbaum.

Flavell, J. H. (1988). The development of children's knowledge about the mind: From cognitive connections to mental representations. In J. W. Astington, P. L. Hamis, \& D. R. Olson (Eds.), Developing theories of mind (pp. 244-267). New York, NY, US: Cambridge University Press.

Friso-van den Bos, I, van der Ven, S. H. G., Kroesbergen, E. H., \& van Luit, J. E. H. (2013). Working memory and mathematics in primary school children: A meta-analysis. Educational Research Review, 10,29-44.

Ghahari, S., \& Basanjideh, M. (2015). Dynamics of strategies-based language instruction: A study of reading comprehension and problem solving abilities via structural equation modeling. RELC Journal, 46(3), 237-253.

Hajloo, N., RezaieSharif, A. (2012). Psychometric properties of Colorado Learning Difficulties Questionnaire (CLDQ), Learning Disabilities, 1(1): 24-43. (in persian)

Hernández, M., Costa, A., \& Humphreys, G. W. (2012). Escaping capture: Bilingualism modulates distraction from working memory. Cognition, 122(1), 37-50.

Hilchey, M. D \& „Klein, R. M. (2011). Are there bilingual advantages on nonlinguistic interference tasks? Implications for the plasticity of executive control processes. Psychonomic Bulletin \& Review, 18(4), 625-658.

Hosseinchari, M., Samawi, A., Kurdestani, D.(2010). Adaption and investigating psychometric properties of Metacognitive Awareness of Reading Strategies Inventory for use in Iranian high School students, Quarterly Journal of Psychological Studies, 6(1):163184. (in persian)

Hu, L. t, \& Bentler ,P. M. (1999). Cutoff criteria for fit indexes in covariance structure analysis: Conventional criteria versus new alternatives. Structural Equation Modeling, 6(1), 1-55.

Javadi, M., Keyvanara, M., Yaghoobi, M., Hassanzadeh, A., Ebadi Z (2010). The relationship between metacognitive awareness of reading strategies and students' academic status in Isfahan University of Medical Sciences. Iranian Journal of Medical Education, 10 (3):246-254. (in persian)

Kitsantas, A. (2013). Fostering college students' selfregulated leaming with learning technologies. Hellenic Journal of Psychology, 10(3), 235-252.

Mahmoodi, M. H, Kalantari, B, \& Ghaslani, R. (2014). Self-regulated learning (sr), motivation and language achievement of Iranian EFL learners. Procedia - Social and Behavioral Sciences, 98, 1062-1068.

Martin, C. D, Molnar, M, \& Carreiras, M. (2016). The proactive bilingual brain: Using interlocutor identity to generate predictions for language processing. Scientific Reports, 6,26171.

Mokhtari, K, \& Reichard, C. A. (2002). Assessing students' metacognitive awareness of reading strategies. Journal of Educational Psychology, 94(2), 249-259.

NaseriJahromi, R., Marzooghi, R. A., RasekhJahromi, A. (2015). The mediator role of self- regulated learning strategies in 
relationship of motivational believes and academic values of general pharmacy students- the case: jahrom university of medical sciences. Joumal of Medical Education Development, 8(17): 102-112. (in persian)

Nokhostin-Goldust, A., Moeini-Kia, M. (2009). The study of relation between self-regulated leaming strategies and motivation strategies for learning with educational performance of students of Ardebil Islamic Azad University, Research In Educational Planing, 1(23): 85100. (in persian)

Pei, L. (2014). Does metacognitive strategy instruction indeed improve chinese efl leamers' reading comprehension performance and metacognitive awareness? Joumal of Language Teaching \& Research, 5(5), 1147.

Pintrich, P.R., \& de Groot, E. V.(1990). Motivational and self-regulated leaming components of classroom academic performance. Joumal of Educational Psychology, 82(1), 33-40.

Poortaheriyan, Z., Khosravi, M., Mohammadifar, M. A. (2014). The relationship between reading metacognition strategies and study habits on academic motivation, Journal of School Psychology, 3(1): 22-36. (in persian)

Ramshe, S. M. H., Hosseiinasab, S. D. (2010). The relationship between sel regulated learning components with intelligence, Shiraz, Joumal of Social And Humanestic Sciences, 30-31(15): 85-96. (in persian)

Roll, I, \& Winne, P. H .(2015). Understanding, evaluating, and supporting self-regulated leaming using learning analytics. Joumal of Learning Analytics, 2(1), 7-12.

Rowe, F. A, \& Rafferty, J. A. (2013). Instructional design interventions for supporting selfregulated leaming: enhancing academic outcomes in postsecondary e-learning environments. Journal of Online Learning \& Teaching, 9(4), 590.

Shafee, B., MehrAlian, Z. (2004). Stutter and speech disabilities in children, Isfahan: Oruj Publication. (in persian)
Tajalli, P, \& Satari, S. (2013). Effectiveness of metacognitive strategies on reading skills of students with hearing disorders. Procedia Social and Behavioral Sciences, 84, 139143.

Vaezi, S., ZolfaghariArdchi, F., Rahimi, E. (2011). Cognitive processing in bilingual and monolingual children, Thinking and Children, 5(3):119-134. (in persian)

Vahedi, S., Jangi, H. (2015). The effect of the math and reading comprehension strategy (SQRQCQ) and metacognitive strategies on math problem solving in elementary students, Thinking and Children, 6(11): 113126. (in persian)

Willcutt, E. G, Boada, R, Riddle, M. W., Chhabildas, N, DeFries, J. C., \& Pennington, B. F. (2011). Colorado leaming difficulties questionnaire: Validation of a parent-report screening measure. Psychological Assessment, 23(3), 778-791.

Yi Chung, L. (2015). Exploring the effectiveness of self-regulated learning in massive open online courses on non-native English speakers. International Journal of Distance Education Technologies (IJDET), 13(3), 6173.

Yidızl, H, Saban, A, \& Ewing, B. F. (2016). The effect of self-regulated leaming on sixthgrade Turkish students' mathematics achievements and motivational beliefs. Cogent Education, 3(1), 1212456.

Zhang, L, \& Seepho, S. (2013). Metacognitive strategy use and academic reading achievement: Insights from a chinese context. Electronic Journal of Foreign Language Teaching, 10(1), 54-69.

Zimmerman, B. J, \& Martinez-Pons, M. (1988). Construct validation of a strategy model of student self-regulated leaming. Journal of Educational Psychology, 80(3), 284-290.

Zimmerman, B. J. (1986). Becoming a self-regulated leamer. Which are the key subprocesses? Contemporary Educational Psychology, 11(4), 307-313. 


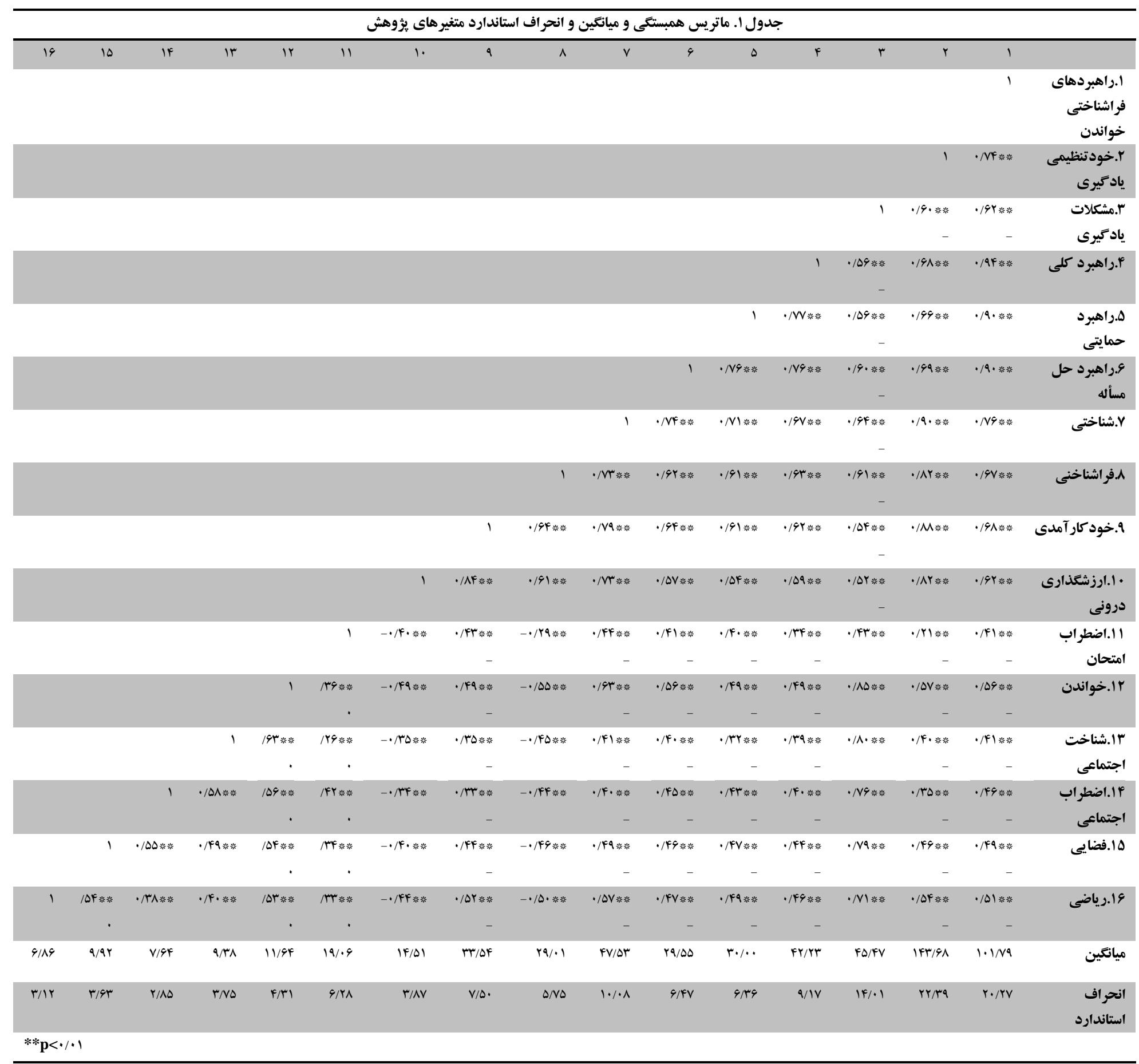

